\title{
PAEDIATRIC WHITE MATTER DISORDERS: MRI AND CT CORRELATION
}

\author{
Ayesha1 , Aejaz Ahmed Gonegandla², Satish Raviraja3, Jaya Nethagani4, Gandrakota Naga Karthik ${ }^{5}$
}

${ }^{1}$ Assistant Professor, Department of Radiodiagnosis, MNJIO \& RCC, Hyderabad.

${ }^{2}$ Senior Resident, Department of Radiodiagnosis, MNJIO \& RCC, Hyderabad.

${ }_{3}^{3}$ Senior Resident, Department of Radiodiagnosis, MNJIO \& RCC, Hyderabad.

4 Professor, Department of Radiodiagnosis, MNJIO \& RCC, Hyderabad.

5 Senior Resident, Department of Radiodiagnosis, MNJIO \& RCC, Hyderabad.

\section{ABSTRACT}

\section{BACKGROUND}

White matter disorders or leukoencephalopathies comprise all disorders that exclusively or predominantly affect the white matter of the brain. There are many different leukoencephalopathies, which can occur at all ages, be progressive or static and be genetic or acquired.[1] Leukodystrophies are genetically determined leukoencephalopathies. The diagnostic workup is complicated. MRI has proven to be pivotal in the diagnostic workup of patients with leukoencephalopathies.[2]

\section{METHODS}

Thirty seven paediatric patients who were under the age of 15 years with white matter abnormalities on MR images were evaluated retrospectively to assess the contribution of MR compared with CT in diagnosing these conditions. In addition, the MR findings in major categories of white matter diseases were analysed for sensitivity in detecting the presence of an abnormality. MRI has virtually replaced all other imaging modalities including CT in the evaluation of white matter diseases due to its excellent graywhite matter resolution and multiplanar imaging capability.

\section{RESULTS}

The categories of white matter diseases included demyelinating disease (8 cases), dysmyelinating disease (12 cases), developmental white matter abnormalities ( 7 cases) and white matter abnormalities of unknown origin (idiopathic) (10 cases) as seen on long TR images. Also MR is found to be more sensitive than CT in detecting disease and the degree of severity in the demyelinating or dysmyelinating categories. MR is also distinctly more useful than CT in demonstrating abnormalities of myelination in cases of developmental delay.

\section{CONCLUSION}

The earlier detection of demyelination by MRI compared to CT is due to its inherent sensitivity to altered water content, especially in white matter. Imaging of spinal cord and orbits can also be done simultaneously by MRI, which helps in differentiating white matter diseases, especially leukodystrophies. MRI in correlation with clinical signs and symptoms is an ideal modality for early diagnosis of white matter diseases.

\section{KEYWORDS}

Paediatric White Matter Disorders: MRI and CT Correlation, MRI is Superior to CT in Detection, Diagnosis of Paediatric White Matter Disease.

HOW TO CITE THIS ARTICLE: Ayesha, Gonegandla AA, Raviraja S, et al. Paediatric white matter disorders: MRI and CT correlation. J. Evolution Med. Dent. Sci. 2016;5(75):5578-5583, DOI: 10.14260/jemds/2016/1260

\section{INTRODUCTION}

White matter diseases are relatively uncommon in children. Hence, clinicians must be aware of their occurrence and able to recognise their MR appearances. White matter diseases in children are traditionally divided into two categories: dysmyelinating diseases and demyelinating diseases.[3] Dysmyelinating diseases also known as leukodystrophies are due to an inherited enzyme deficiency that causes abnormal formation, destruction and turn-over of myelin. Demyelinating diseases whereas involve destruction of intrinsically normal myelin.

Financial or Other, Competing Interest: None.

Submission 27-08-2016, Peer Review 08-09-2016,

Acceptance 10-09-2016, Published 19-09-2016.

Corresponding Author:

Dr. Ayesha,

\#8-3-214/50B,

Srinivasa Colony (West),

Hyderabad-500038.

E-mail: ayesharadio@gmail.com

DOI: $10.14260 /$ jemds $/ 2016 / 1260$

\section{Classification of White Matter Diseases}

Based on Valk and Van der Knaap classification, white matter disorders are broadly classified as dysmyelinating diseases and demyelinating diseases. ${ }^{[4]}$

\begin{tabular}{|c|c|}
\hline $\begin{array}{l}\text { Dysmyelinating } \\
\text { Diseases (Hereditary } \\
\text { Leukodystrophies } \\
\text { A. Lysosomal } \\
\text { Disorders } \\
\text { - Metachromatic } \\
\text { Leukodystrophy } \\
\text { (MLD) } \\
\text { - Krabbe's (Globoid Cell) } \\
\text { Leukodystrophy }\end{array}$ & $\begin{array}{l}\text { B. Peroxisomal Disorders } \\
\text { - Adrenoleukodystrophy } \\
\text { (ALD) } \\
\text { - Zellweger- } \\
\text { Cerebrohepatorenal } \\
\text { Syndrome }\end{array}$ \\
\hline $\begin{array}{ll}\text { C. } & \begin{array}{l}\text { Amino Acid and } \\
\text { Organic Acid } \\
\text { Metabolic Disorders }\end{array} \\
\text { - } & \text { Canavan's Disease } \\
\text { - } & \text { Maple Syrup Urine } \\
& \text { Disease }\end{array}$ & 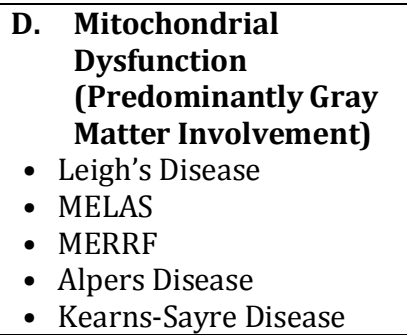 \\
\hline
\end{tabular}




\begin{tabular}{|c|c|}
\hline $\begin{array}{l}\text { White Matter Disease of } \\
\text { Unknown Metabolic } \\
\text { Defect } \\
\text { - Pelizaeus-Merzbacher } \\
\text { Disease } \\
\text { - Alexander's Disease }\end{array}$ & \\
\hline $\begin{array}{l}\text { Demyelinating Diseases } \\
\text { (Acquired } \\
\text { Leukodystrophies) } \\
\text { A. Inflammatory } \\
\text { - Multiple Sclerosis and } \\
\text { Variants (MS) } \\
\text { - Acute Disseminated } \\
\text { Encephalomyelitis } \\
\text { (ADEM) } \\
\text { - Acute Haemorrhagic } \\
\text { Encephalomyelitis } \\
\text { (AHEM) }\end{array}$ & $\begin{array}{ll}\text { B. } & \text { Infections } \\
\text { - } & \text { HIV Encephalopathy } \\
\text { - } & \text { Progressive Multifocal } \\
& \text { Leukoencephalopathy } \\
& \text { (PML) } \\
\text { - Subacute Sclerosing } \\
\text { Panencephalitis (SSPE) } \\
\text { - Herpes Simplex and Other } \\
\text { - } \text { Infections (HSE) } \\
\text { - Creutzfeldt-Jakob Disease. }\end{array}$ \\
\hline $\begin{array}{l}\text { C. Toxic-Metabolic } \\
\text { - Central Pontine } \\
\text { Myelinolysis } \\
\text { - Vitamin B12 } \\
\text { Deficiency } \\
\text { - Carbon Monoxide } \\
\text { Poisoning } \\
\text { - Organic Compounds- } \\
\text { Hexachlorophene. } \\
\text { Toluene } \\
\text { - Chemotherapy. } \\
\text { Radiation } \\
\text { Trauma } \\
\text { - Diffuse Axonal Injury } \\
\text { Vascular } \\
\text { - Periventricular } \\
\text { Leukomalacia (PVL) } \\
\text { - Aging changes } \\
\text { Affecting White Matter }\end{array}$ & \\
\hline
\end{tabular}

Using Poser's classification of white matter diseases, demyelinating lesions further may be divided into primary disorders, such as Multiple Sclerosis (MS) and Acute Disseminated Encephalomyelitis (ADEM), and secondary disorders whose origins include toxic or anoxic deficiency syndromes, viral disorders such as progressive multifocal leukoencephalopathy and primary neuronal lesion Wallerian degeneration.[1] The more common primary dysmyelinating lesions include Metachromatic Leukodystrophy (MLD), Krabbe disease, Canavan disease, Alexander disease and Pelizaeus-Merzbacher Disease (PMD). The predominant secondary dysmyelinating disorders fall into the metabolic category. Poser[1] notes that adrenoleukodystrophy exhibits characteristics of both the demyelinating and dysmyelinating disorders. In our study two other categories of diseases that produce white matter abnormalities on MR: delayed myelination on a developmental basis and idiopathic paediatric white matter abnormalities are also included. This study though focuses on the MR diagnosis of paediatric white matter abnormalities.

\section{Subjects and Methods}

Thirty seven patients under 15 years old who were diagnosed as having abnormal white matter on MR were included in this study. Many paediatric cases were referred to our hospital from the nearby government children hospital too. The study population included 16 girls and 19 boys ranging in age from 5 months to 15 years. Requirements for admission to the study were that the patient was under 18 and that a white matter abnormality was found on long TR-MR images. The routine MR study performed on a Philips Achieva 1.5 Tesla MRI system included sagittal short spin-echo images 650/30/2 (TR/TE/excitations) and axial and coronal long spin-echo images 3000/40, 90/2 and if the patient was under 2 years old $3500 / 40,160 / 2$. Twenty seven patients had CT scans. Two patients had both CT and cranial sonographic examinations. Three patients had no other studies, and information regarding outside examinations was unavailable in three other patients.

\section{RESULTS}

The MR findings were categorised on the basis of clinical information. Of the 37 patients, eight had demyelinating disease, twelve had dysmyelinating disease, seven were developmentally delayed and ten had white matter abnormalities with no known cause (Tables 1-4). In 18 cases, MR identified additional lesions which were not visualised on CT. These lesions appeared predominantly patchy, focal areas of increased white matter signal on long TR images in patients with demyelinating disease or in patients with white matter abnormalities with no known cause. In three cases, the CT scans were unavailable for review. In the dysmyelinating diseases, it was observed that MR was equivalent to CT in identifying white matter abnormalities. Whether MR could be diagnostic early in the clinical course of the disease when CT is negative as suggested by other authors, could not be evaluated in our group of patients because they were all studied in the subacute phases of their disease.[5] Three of the six patients with perinatal asphyxia and/or developmental delay had a CT scan. This patient had a documented germinal matrix haemorrhage, and CT demonstrated periventricular low absorption in the white matter with minimal ventricular dilatation. On MRI a rind of hemosiderin surrounding the lateral ventricles was seen, which suggested old haemorrhage.

\begin{tabular}{|c|c|c|c|}
\hline $\begin{array}{c}\text { Clinical } \\
\text { Diagnosis }\end{array}$ & $\begin{array}{l}\text { Case } \\
\text { No. }\end{array}$ & CT & MRI \\
\hline $\begin{array}{l}\text { Acute } \\
\text { Disseminated } \\
\text { Encephalitis }\end{array}$ & 4 & $\begin{array}{l}\text { One Lesion } \\
\text { in Centrum } \\
\text { Semiovale } \\
\text { One Lesion } \\
\text { in Centrum } \\
\text { Semiovale } \\
\text { Normal } \\
\text { Normal } \\
\text { Normal } \\
\text { Two } \\
\text { Lesions in } \\
\text { Centrum } \\
\text { Semiovale }\end{array}$ & $\begin{array}{l}\text { Three White } \\
\text { Matter Lesions in } \\
\text { Centrum } \\
\text { Semiovale in Right } \\
\text { and Left } \\
\text { Two White Matter } \\
\text { Lesions in } \\
\text { Centrum } \\
\text { Semiovale in Right } \\
\text { and Left } \\
\text { Parietal White } \\
\text { Matter } \\
\text { Temporo-Parietal } \\
\text { White Matter } \\
\text { One Lesion } \\
\text { Centrum } \\
\text { Semiovale } \\
\text { Two White Matter } \\
\text { Lesions in } \\
\text { Centrum } \\
\text { Semiovale in Right } \\
\text { and Left }\end{array}$ \\
\hline $\begin{array}{l}\text { Multiple } \\
\text { Sclerosis }\end{array}$ & 2 & $\begin{array}{l}\text { Normal } \\
\text { Multiple } \\
\text { Lesions } \\
\end{array}$ & $\begin{array}{l}\text { Four Lesions Near } \\
\text { Corpus Callosum } \\
\text { Multiple Lesions }\end{array}$ \\
\hline & & myelinati & orders \\
\hline
\end{tabular}




\begin{tabular}{|c|c|c|c|}
\hline Clinical Diagnosis & $\begin{array}{c}\text { Case } \\
\text { No. }\end{array}$ & CT & MRI \\
\hline Canavan Disease & 1 & $\begin{array}{l}\text { Mild Hypodensity } \\
\text { Periventricular Region } \\
\text { Normal }\end{array}$ & $\begin{array}{l}\text { Bilateral White Matter Abnormal Signal Involving the } \\
\text { Subcortical U Fibers. Increased NAA on MRS } \\
\text { Bilateral White Matter Abnormal Signal Involving the } \\
\text { Subcortical U-Fibers. Increased NAA on MRS }\end{array}$ \\
\hline Adrenoleukodystrophy & 1 & $\begin{array}{l}\text { Periventricular Mild } \\
\text { Hypodensity near Occipital } \\
\text { Horns Lateral Ventricle }\end{array}$ & $\begin{array}{l}\text { B/l White Matter Hyperintensities in Occipital Horn of } \\
\text { Lateral Ventricle }\end{array}$ \\
\hline $\begin{array}{l}\text { Metachromatic } \\
\text { Leukodystrophy }\end{array}$ & 1,2 & $\begin{array}{l}\text { Non-specific Low Density of } \\
\text { Deep WM } \\
\text { Normal }\end{array}$ & $\begin{array}{l}\text { B/l and Symmetric T2 and Flair Hyperintensities are } \\
\text { Noted in the Periventricular and Deep White Matter } \\
\text { with Relative Sparing of the Subcortical U-Fibers. } \\
\text { B/l and Symmetric T2 and FLAIR Hyperintensities are } \\
\text { Noted in the Periventricular and Deep White Matter } \\
\text { with Relative Sparing of the Subcortical U-fibers }\end{array}$ \\
\hline Vander Knaap Disease & 1 & $\begin{array}{l}\text { Hypodense Lesions in } \\
\text { Posterior Frontal and } \\
\text { Temporal Lobe }\end{array}$ & $\begin{array}{l}\text { T2 Hyperintense, T1/FLAIR Hypointense Cystic Lesions } \\
\text { in Posterior Frontal and Temporal Lobe }\end{array}$ \\
\hline
\end{tabular}

\begin{tabular}{|c|c|c|c|c|c|}
\hline Case No. & Age & Gender & Clinical Diagnosis & CT & MR \\
\hline \begin{tabular}{|l|}
1 \\
\end{tabular} & 13 months & $\mathrm{F}$ & Spasticity, Developmental Delay & Normal & Relatively delayed myelination \\
\hline 2 & 4 years & M & Seizures, Developmental Delay & Abnormal & $\begin{array}{c}\text { Periventricular Disease, Ependymal } \\
\text { Hemosiderin }\end{array}$ \\
\hline 3 & 7 Years & M & $\begin{array}{c}\text { Sensorineural Hearing Loss, } \\
\text { Developmental Delay }\end{array}$ & CT Not Done & Periventricular Disease \\
\hline 4 & 15 Months & $\mathrm{M}$ & Developmental Delay, Exotropia & CT Not Done & Altered White Matter Signals \\
\hline 5 & 5 Years & $\mathrm{F}$ & Developmental Delay & Normal & Altered White Matter Signals \\
\hline 6 & 18 Months & $\mathrm{M}$ & Developmental Delay & Normal & Altered White Matter Signals \\
\hline 7 & 12 Months & $\mathrm{M}$ & Developmental Delay & Normal & Altered White Matter Signals \\
\hline 8 & 5 Years & M & Developmental Delay & $\begin{array}{l}\text { Ill Defined } \\
\text { Hypodensity }\end{array}$ & Periventricular Altered Intensities \\
\hline 9 & 3 Years & $\mathrm{F}$ & Developmental Delay & Normal & Altered White Matter Signals \\
\hline 10 & 4 Years & M & Developmental Delay & $\begin{array}{l}\text { Periventricular } \\
\text { Hypodensity }\end{array}$ & Periventricular Altered Intensities \\
\hline 11 & 28 Months & $\mathrm{F}$ & Developmental Delay & $\begin{array}{l}\text { Ill Defined } \\
\text { Hypodensity }\end{array}$ & Altered White Matter Signals \\
\hline 12 & 6 Years & $\mathrm{F}$ & Developmental Delay & Normal & \\
\hline \multicolumn{6}{|c|}{ Table 3: Developn } \\
\hline
\end{tabular}

\begin{tabular}{|c|c|c|c|c|c|}
\hline Case No. & Age & Gender & Clinical Diagnosis & CT & MR \\
\hline 1 & 5 Years & $\mathrm{F}$ & Ataxia, Developmental Delay & Normal & Diffuse High Signal White Matter \\
\hline 2 & 4 Years & M & $\begin{array}{l}\text { Seizures, Developmental Delay, } \\
\text { Fine Motor Difficulties }\end{array}$ & $\begin{array}{l}\text { CT Not } \\
\text { Done }\end{array}$ & $\begin{array}{l}\text { Patchy Periventricular } \\
\text { White Matter Disease }\end{array}$ \\
\hline 3 & 20 Months & M & $\begin{array}{l}\text { Sensorineural Hearing Loss, } \\
\text { Developmental Delay }\end{array}$ & Abnormal & $\begin{array}{l}\text { Tiny Focal Lesions, } \\
\text { Centrum Semiovale }\end{array}$ \\
\hline 4 & 5 Years & $\mathrm{F}$ & $\begin{array}{c}\text { Developmental Delay, } \\
\text { Seizures }\end{array}$ & Normal & $\begin{array}{l}\text { Patchy Periventricular } \\
\text { White Matter Signals }\end{array}$ \\
\hline 5 & 6 Years & $\mathrm{F}$ & Hemifacial Palsy & Normal & $\begin{array}{l}\text { Ipsilateral Parietal White } \\
\text { Matter Focal Lesions }\end{array}$ \\
\hline 6 & 4 Years & M & $\begin{array}{l}\text { Seizures, Developmental } \\
\text { Disorders }\end{array}$ & Normal & $\begin{array}{c}\text { Patchy Periventricular } \\
\text { White Matter Signals }\end{array}$ \\
\hline 7 & 3 Years & M & $\begin{array}{l}\text { Developmental Delay, } \\
\text { Seizures }\end{array}$ & Normal & $\begin{array}{l}\text { Periventricular White } \\
\text { Matter Signals }\end{array}$ \\
\hline 8 & 4 Years & $\mathrm{F}$ & $\begin{array}{l}\text { Fine Motor Disturbances, } \\
\text { Developmental Delay }\end{array}$ & Normal & $\begin{array}{c}\text { Patchy Periventricular } \\
\text { White Matter }\end{array}$ \\
\hline 9 & 15 Months & M & Developmental Delay & $\begin{array}{l}\text { CT Not } \\
\text { Done }\end{array}$ & $\begin{array}{c}\text { Patchy Periventricular } \\
\text { White Matter }\end{array}$ \\
\hline 10 & 13 Years & M & Development Delay & Normal & Periventricular White Matter \\
\hline
\end{tabular}




\section{DISCUSSION}

In this study, paediatric white matter diseases were divided into four categories based on high-intensity abnormalities seen on long TR images and were correlated with clinical information, i.e. demyelinating disease, dysmyelinating disease, developmental delay (of myelination) and white matter abnormalities of unknown origin (Idiopathic). In this case series, it was found that CT was less sensitive to the extent of and/or number of patchy lesions in demyelinating disease. However, when CT findings were taken in combination with clinical history, CT was found to be diagnostic in all eight cases. The findings on CT must be correlated with viral titres, neurologic history and examination, especially in demyelinating diseases of childhood. Two patients had an abnormal CT with non-enhancing hypodense focal lesions on CT, but in each case more lesions were demonstrated on MR.

The MR appearance in Acute Disseminating Encephalomyelitis (ADEM) varied from small focal asymmetrical lesions to large confluent tumefactive lesions with less mass affect than expected for the size involving either the supratentorial or infratentorial regions or both and even the spinal cord. Lesions are usually bilateral, involvement of grey matter (Basal ganglia and thalami is uncommon which distinguishes it from Multiple Sclerosis (MS). In MS, pericallosal interface involvement is characteristic, which is unusual in ADEM. Lesions may also shoe peripheral restricted diffusion in ADEM. Kesselring J et al evaluated 12 patients with ADEM with MRI and noted that multifocal white matter lesions indistinguishable from MS were found in 10 patients, but follow-up MRI showed new lesion in only 1 case thus postulating that follow-up MR may be helpful in distinguishing it from MS.[6]
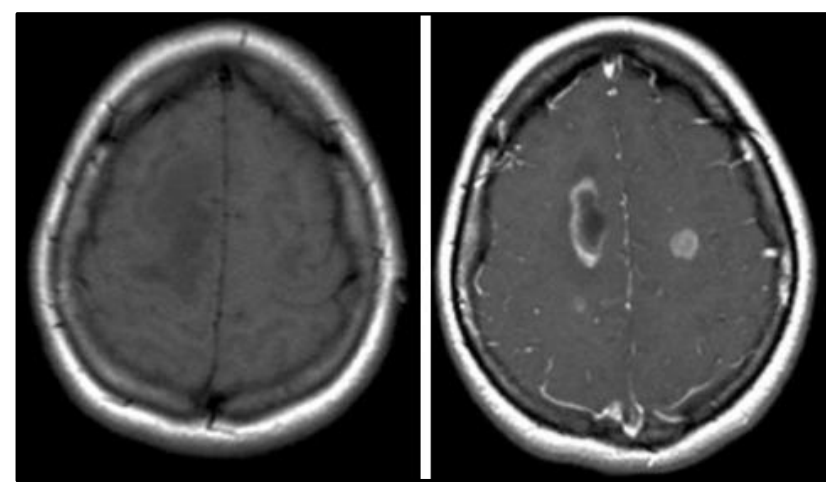

Bilateral Asymmetric Altered Signal Intensity Lesions which are Hypointense on T1 and Hyperintense on T2 with Open Ring Enhancement are Noted in the Centrum Semiovale, Characteristic of Demyelination

In one patient with ADEM, CT was normal. MR consistently depicted more lesions per patient than did CT in this category of patients. This sensitivity of long TR images is well described in the MR literature, ${ }^{[7]}$ and as is also apparent from the CT and pathologic literature, ${ }^{[8]}$ the dysmyelinating disorders demonstrated diffuse confluent high signal intensity in the white matter on long TR spin-echo images. We did not have any patients with a biochemically or biopsy-proved dysmyelinating disorder with patchy or focal white matter changes. We did however have two somewhat atypical cases of Alexander disease, both biopsy-proved. One patient had diffuse cerebellar high signal intensity. The second patient had periventricular high signal, which was more prominent posteriorly. As noted in the literature, ${ }^{[9]}$ Alexander disease usually manifests with abnormal white matter in the frontal region. Rarely, it involves the basal ganglia. The sensitivity of MR in these cases may result in widening the spectrum of radiologic manifestations of this disease. It is also possible that with further clinical follow-up our cases may demonstrate more typical findings and that presently we may just be imaging one point on the continuum of the disease.

In MLD, MRI reveals extensive symmetrical increase in the signal intensity of periventricular and subcortical white matter on T2-weighted images resulting in a butterfly configuration. The demyelination initially spares the subcortical $U$ fibers and the basal ganglia and shows no enhancement on contrast administration. The lesion usually begins in the frontal region and shows posterior progression unlike other leukodystrophies. The other feature which differentiates it from other leukodystrophies is the presence of cerebellar lesions. Cortical atrophy occurs later in the course of the disease with involvement of arcuate fibers and the cerebellar white matter. ${ }^{[10]}$ Alves D et al[11] in a study of 4 cases of metachromatic leukodystrophy in a family noted that the late infantile form is the more common presentation than juvenile and adult variants.

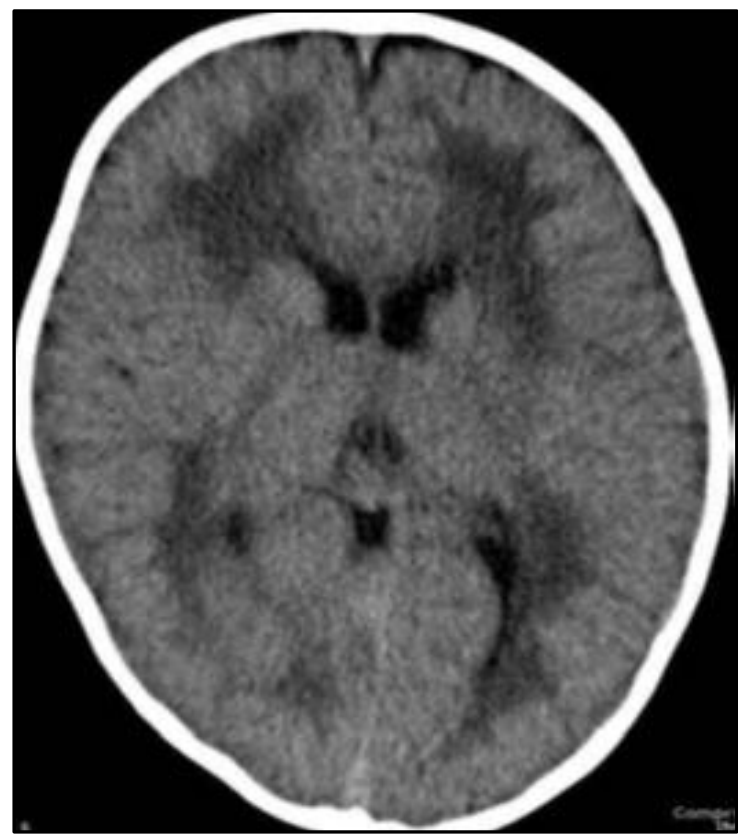

On CT Scan, Periventricular Hypodensities are Seen
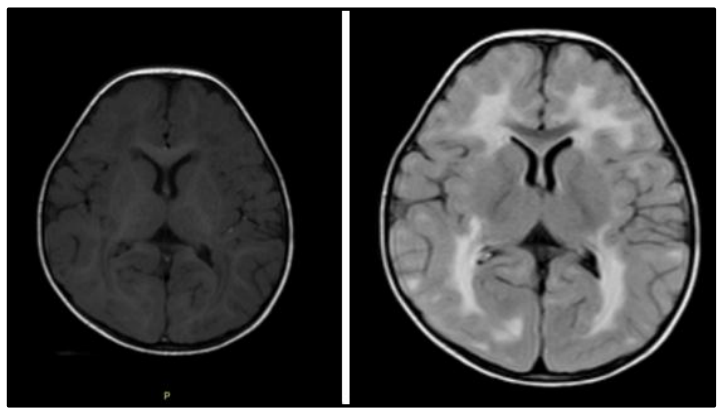

MRI-Extensive Bilateral and Symmetric T2 and FLAIR Hyperintensities are Noted in the Periventricular and Deep White Matter with Relative Sparing of the Subcortical U-Fibers 
The classic MR appearance in ALD is the bilateral and symmetrical involvement of the occipital lobes and the splenium of corpus callosum with marked prolongation of T1 and $\mathrm{T} 2$ relaxation times. The peripheral white matter is spared in the early phase of the disease. The corticopontine and corticospinal tracts in the brain stem show T2 prolongation with typical involvement of splenium. In a study by Masdeu et al,[12] an "open ring sign" characteristic of demyelinating diseases was seen in demyelinating disorders (66\%) more than the non-demyelinating disorders (7\%). And of the total cases, ! $2 \%$ of demyelinating disorders were ALD cases. Our study demonstrated similar findings of bilatral symmetrical occipital periventricular region involvement.

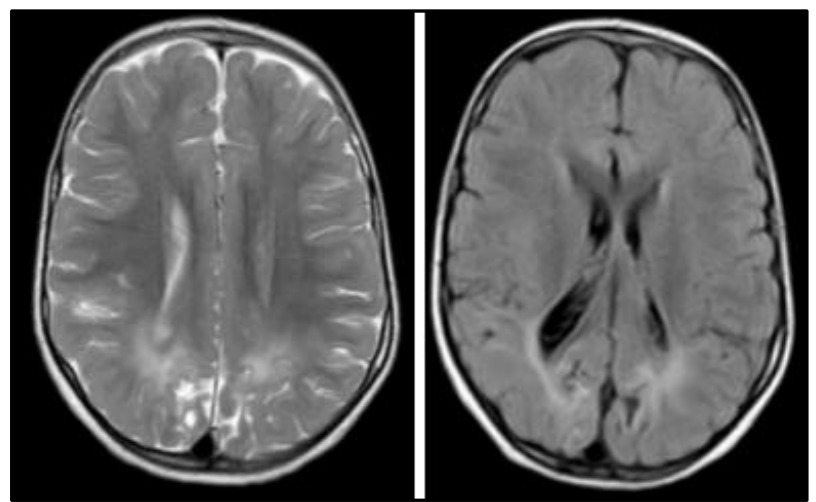

Bilateral and Symmetrical Involvement of the Occipital Lobes, which are T2/FLAIR Hyperintense

In Canavan's dysmyelinating disorder, MR appearance is that of megalencephaly with diffuse and symmetrically increased signal seen throughout the white matter on T2weighted images and relative sparing of the internal capsules. The demyelination is known to begin in the subcortical arcuate[13] fibers with the globus pallidus more commonly affected. Marks HG et al[14] suggested that MR spectroscopy by measurement of NAA is particularly useful to confirm the diagnosis in suspected cases of Canavan's disease.

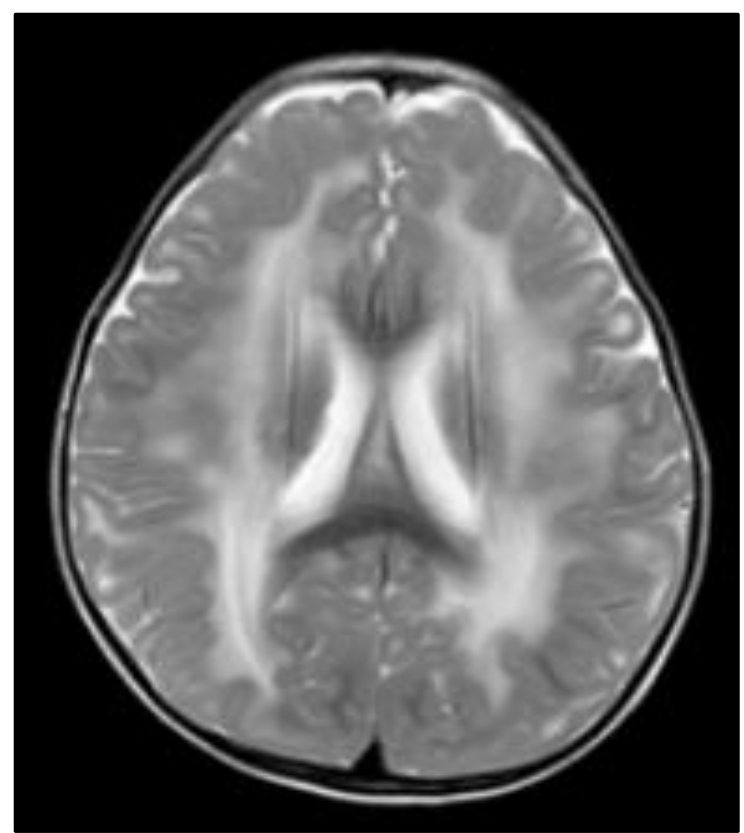

Megalencephaly with Diffuse and Symmetrically Increased Signal seen throughout the White Matter on T2-Weighted Images in a Case of Canavan's

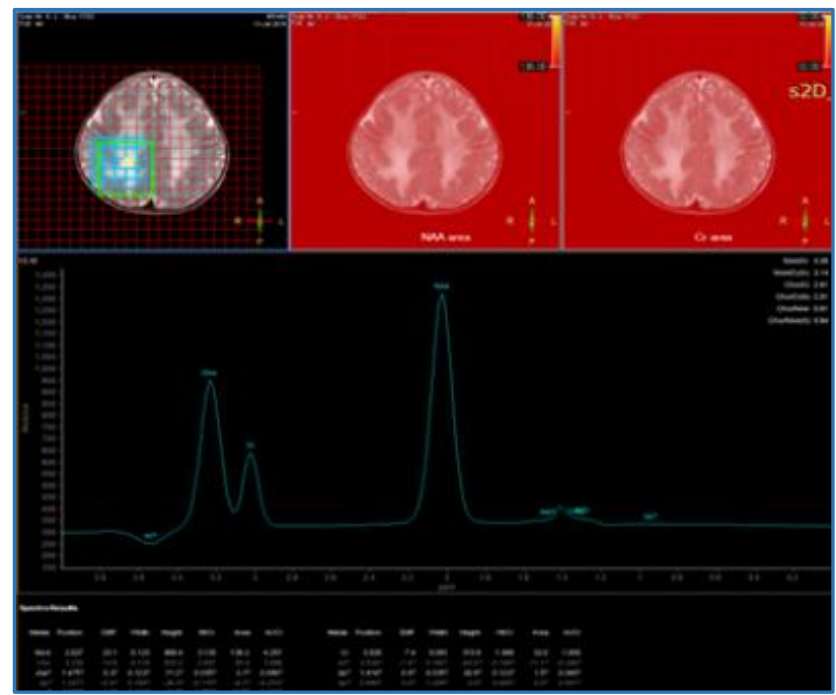

On MRS, the Characteristic NAA Peak in Canavan's is Seen

Megalencephalic Leukoencephalopathy (MLC) with subcortical cysts is a rare disease first described by Van der Knaap et al in 1995.[15] It is a relatively new entity of neurodegenerative disorder, which is characterised by infantile onset macrocephaly, cerebral leukoencephalopathy and mild neurological symptoms and an extremely slow course of functional deterioration.[15] Almost all patients have epilepsy from an early age. The MR findings are often diagnostic of MLC. MR shows 'swollen white matter' and diffuse supratentorial symmetrical white matter changes in the cerebral hemispheres with relative sparing of central white matter structures like the corpus callosum, internal capsule and brain stem. Subcortical cysts are almost always present in the anterior temporal region and are also frequently noted in frontoparietal region. Grey matter is usually spared. The disease is more commonly found in Indians and Indian patients with megalencephaly and MR changes that show extensive white matter changes with temporal cysts should raise suspicion for MLC, especially in Agarwal Communities of North India.[16] However, our patient did not belong to the North Indian ethnicity.
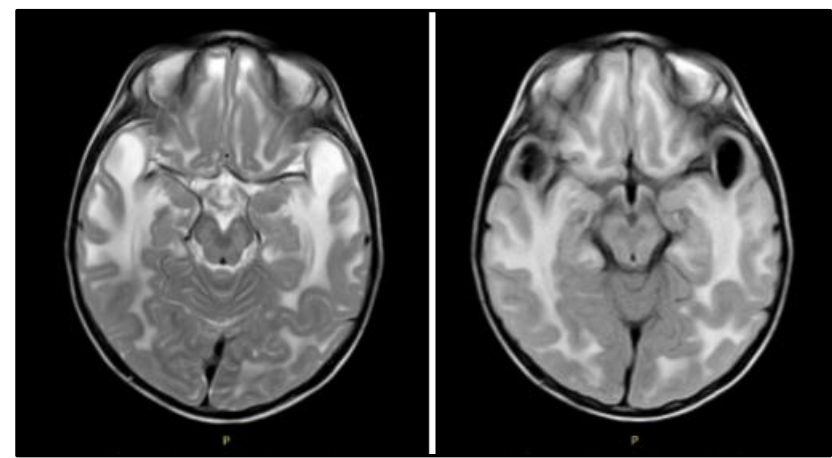

Well-Defined Symmetrical Subcortical Cysts were Noted in Anterior Temporal Lobe which are Hyperintense on T2 and Hypointense on FLAIR Sequence

In children with developmental delay MR is more useful than CT, since the progression of myelination can be evaluated with greater sensitivity. Old hemosiderin deposits in the germinal matrix, which occur usually in developmental delay are also made only by MR. Clinical correlation and MR followup is necessary to fully evaluate the role of MR in this group of patients. 

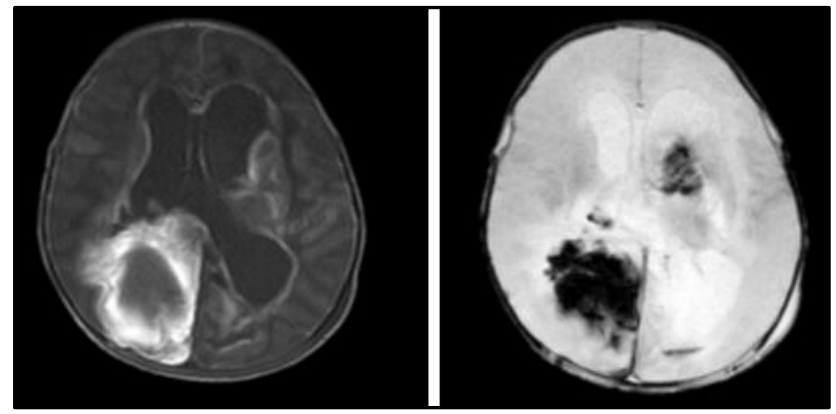

Large T1 Hyperintense Lesion Noted in Left Caudothalamic Groove and Right Parieto-Occipital Region which show Bloomimg on GRE Sequences

The last group of paediatric white matter diseases are those of unknown origin. These patients with idiopathic white matter abnormalities had variably sized patchy focal areas of high signal intensity on long TR images in the white matter with no significant relation to the neurologic symptoms or examination. In these patients there was no history of trauma, drug or radiation exposure or prematurity.

\section{CONCLUSION}

37 paediatric patients with white matter disease were evaluated by MR and were placed into four categories on the basis of long TR-MR findings and clinical information: demyelinating, dysmyelinating, delayed developmental and idiopathic white matter abnormalities. MR was found to be more sensitive than CT in detecting white matter disease in demyelinating or dysmyelinating categories, and MR also more sensitive than CT in determining the extent of involvement of the disease. In the developmental group, the pattern of myelination could be assessed and definitive evidence of old haemorrhage could be determined. In the idiopathic groups, MR helped in identifying the existence of disease which usually was not found by CT. Thus, MR may serve to redefine and broaden the disease spectrum of reported white matter abnormalities in children and in any suspicion of white matter diseases MR should be advised.

\section{REFERENCES}

1. Poser CM. Disease of the mylen sheath. In: Minckler J, ed. Pathology of the nervous system. New York: McGraw-Hill 1968:767-821.

2. Nowell MA, Hackney DB, Zimmerman RA, et al. Immature brain: spin-echo pulse sequence parameters for highcontrast MR imaging. Radiology 1987;162(1 Pt 1):272-3.
3. Van der Voorn JP, Pouwels PJ, Hart AA, et al. Childhood white matter disorders: quantitative MR imaging and spectroscopy. Radiology 2006;241(2):510-7.

4. Edelman RR. Clinical magnetic resonance imaging. $3^{\text {rd }}$ edn. Philadelphia: Elsevier Saunders 2006:1572-1606.

5. Kingsley DP, Kendall BE. Demyelinating and neurodegenerative disease in childhood: CT appearances and their differential diagnosis. J Neuroradiol 1951;8:243-55.

6. Kesselring J, Miller DH, Robb SA, et al. Acute disseminated encephalomyelitis-MRI findings and the distinction from multiple sclerosis. Brain 1990;113(Pt 2):291-302.

7. Atlas SW, Grossman RI, Goldberg HI, et al. MR diagnosis of acute disseminated encephalomyelitis. J Comput Assist Tomogr 1986;10(5):798-801.

8. Barnes DM, Enzmann DR. The evolution of white matter disease as seen on computed tomography. Radiology 1981;138(2):379-83.

9. Farrell $\mathrm{K}$, Chuang S, Becker LE. Computed tomography in alexander's disease. Ann Neuro 1984;15(6):605-7.

10. Demaerel P, Faubert C, Wilms G. MR findings in leukodystrophy. Neuroradiology 1991;33(4):368-71.

11. Alves D, Pires MM, Guimaraes A, et al. Four cases of late onset metachromatic leukodystrophy in a family: clinical, biochemical and neuropathological studies. J Neurol Neurosurg Psychiatry 1986;49(12):1417-22.

12. Masdeu JC, Moreira J, Trasi S, et al. The open ring. A new imaging sign in demyelinating disease. J Neuroimaging 1996;6(2):104-7.

13. Fedrizzi E, Inverno M, Bruzzone MG, et al. MRI features of cerebral lesions and cognitive functions in preterm spastic diplegic children. Pediatr Neurol 1996;15(3):20712.

14. Marks HG, Caro PA, Wang ZY, et al. Use of computed tomography, magnetic resonance imaging and localized 1H magnetic resonance spectroscopy in canavan's disease: a case report. Ann Neurol 1991;30(1):106-10.

15. Van der Knaap MS, Barth PG, Stroink H, et al. Leukoecephalopathy with swelling and a discrepantly mild clinical course in eight children. Ann Neurol 1995;37(3):324-34.

16. Gorospe JR, Singhal BS, Kainu T, et al. Indian Agarwal megalencephalic leukodystrophy with cysts is caused by a common MLC1 mutation. Neurology 2004;62(6):87882. 